\title{
Sprouting STEMs in a Professional Development School Relationship*
}

\author{
Margaret M. Ferrara \\ University of Nevada Reno (UNR), Reno, USA
}

\begin{abstract}
This is a case study of a middle school in the western part of the United States (U.S.) and a secondary education program in the College of Education at the University of Nevada Reno (UNR). The partnership began as a grant-funded activity as part of the science, technology, engineering, and math (STEM) college-wide program and has grown into a systematic and highly collaborative partnership that is reciprocal and focuses on teacher preparation and teacher in-service. This paper describes a systematic study of the first year of implementation and captures the voices of multiple players: university professors, field-based faculty, school support liaisons for practice and internships, and university supervisors. The first year of this relationship grew from a grant-funded initiative with a focus on STEM to a well-developed and research-based school-university partnership based on content beyond STEM.
\end{abstract}

Keywords: collaboration, Professional Development Schools (PDSs), science, technology, engineering, and math (STEM) education, STEAM education, teacher preparation

\section{Introduction}

The idea of partnerships is not new in education. Today's partnerships share a common theme-a relationship with a school, a school district, or a community program, but the elements that create this partnership have a unique set of features. Partnerships depend on high-level of commitment, mutual trust, common goals, and equal ownership (Zimpher \& Howey, 2005). Professional Development Schools (PDSs) materials, such as planning documents like Holmes Group's (1990) Tomorrow's School and the PDS Vision Statement (National Center for Restructuring Education, Schools, and Teaching [NCREST], 2017) laid the foundation for helping to strengthen the connection between school and university partners. The support for PDSs was touted in 1997 as a strong model for change and more importantly, as a supportive model for teacher education and professional development (Darling-Hammond, 1997; Murrell, 1998) and further supported by the writings of Boydell, Rugkasa, Hoggett, and Cummins in 2003.

\section{The Challenge in Building School-University Partnerships}

In today's schools, a partnership may emerge when there is an issue that is confounding the educational system. For example, a school or a school district may approach an educational program in higher education when there is evidence that the school district is experiencing lackluster test scores, poor teacher retention, and

\footnotetext{
* Acknowledgement: Thanks to Kathryn Fitzpatrick and Jennifer Malaterre (Dilworth Middle School [DMS]) and Washoe County School), and Kari Hyland (University of Nevada Reno [UNR]) in data collection.

Margaret M. Ferrara, Ph.D., associate professor, College of Education, University of Nevada Reno (UNR).
} 
frightening graduation rates (e.g., Darling-Hammond, 2005; 2008)

While there are stories of successful partnerships, some fail to affect systemic changes needed to improve the lives of the students they serve. Fixing one point on the educational continuum, such as better after-school programs have a limited impact on the making a significant difference on the larger issue and the need to bring all elements together to form a powerful team approach (Kania \& Kramer, 2011). In many cases, an initiative, such as an improved after-school program gets muddled with other agencies in the area who are also working on aspects of after-school programs. Ultimately, the partnership becomes one of the many well-meaning groups who end up completing for funding and resources while duplicating the efforts of other partnerships trying to solve the same problem. Bombarded by grant requests, would-be funders are forced to choose grantees that they believe have the best chance of solving an education reform problem. Those who are brought to the table to fund a project bring individual priorities. Sometimes, it is not the desire of the school or the partnership team from the teacher preparation program at the university (Kania \& Kramer, 2011).

Another challenge in building school-university partnerships is that in large school districts, there are complexities, such as those who will be selected to serve as a partner. It is noted that schools with students of different race and class backgrounds, e.g., Title 1 schools, are more likely to be selected as partners (Mohr \& Dichter, 2003). Title 1 funds aim to bridge the achievement gap between low-income students and other students. The United States (U.S.) Department of Education provides supplemental funding to local school districts to meet the needs of at-risk and low-income students. Annually, it provides over $\$ 14$ billion to school systems across the country for students at risk of failure and living at or near poverty. In fact, over the course of the 2009-2010 academic years, federal funding through this program was used by over 56,000 public schools nationwide in order for struggling students to meet state standards in a variety of subject areas.

\section{Science, Technology, Engineering, and Maths and the Extended Version}

Today's school selection for who will become a PSD is typically based on multiple variables beyond diversity and socio-economic level. One of the driving attributes in a school selection today is a program that already has a supportive funding source, like a federal grant project centered on science, technology, engineering, and math (STEM). The intent of STEM is not to teach each of these disciplines separately, but to bring the curriculum of all four disciplines together in an inter-disciplinary and applied approach based on real-world applications. The National Governors Association (NGA) (2007) had defined STEM more appropriately, that was, having students in the integration of various subjects, cohorts, and community involvement.

STEM literacy is an interdisciplinary area of study that bridges the four areas: science, technology, engineering, and mathematics. STEM literacy does not simply mean achieving literacy in these four strands or silos. Consequently, a STEM classroom shifts students away from learning discrete bits and pieces of phenomenon and rote procedures and toward investigating and questioning the interrelated facets of the world (NGA, 2007, p. 7).

STEM programs in many schools have recognized there is a need to not only integrate the four subjects of mathematics, science, technology, and engineering, but also other content, namely, the unified arts (e.g., art and music), English, and social studies (e.g., Corlu, Capraro, \& Capraro, 2014). One way that this is achieved is through using project-based learning (Buck Institute for Education, 2017; Fishbough, 2007). The method uses a systematic inquiry process during an extended period of time to investigate a collaboratively developed 
question. Projects most often begin with students identifying a need in society and then perform research work with their community and design a solution (Garrison \& Chandler, 2009). The solution then needs to be tested using a team approach and a final project is then showcased in a school-wide or even a community presentation.

Another aspect of STEM and the extended version-science, technology, engineering, arts, and math (STEAM), is that there is a greater impact when the projects are linked to community involvement. These include using community members, such as businesses, government agencies, research lab scientists, and university faculty (Morrison, Roth, \& French, 2015) as resources for additional course instruction, field trip opportunities, and externships and internships (Kasza \& Slater, 2017).

National awareness if also focused on the need to students especially in the early elementary grades to become more fluent in literacy. The movement known as the "Read by Grade 3" campaign does not stop by Grade 3. It is recognized in school settings beyond elementary school that the decision on the focus on learning need not be an either STEM or literacy. Research on cognition, pedagogy, and brain function shows that students gain more knowledge and skills in literacy and STEM subjects when these are both taught in tandem. The mandate, funded in the state of Nevada, used a roll-out model set up as a statute. Senate Bill (SB) 391 requires all public school districts and charter schools to develop local kindergarten through Grade 3 (K-3) literacy plans aimed at improving the literacy of all K-3 grade level students. Also, it requires every elementary school in Nevada to designate a reading "learning strategist" to provide literacy-based professional learning, coaching, and guidance for all kindergarten through Grade 12 (K-12) teachers at the site. The impact of this legislation is that students entering middle school will be readers who will be prepared to engage in programs, such as STEM or STEAM.

The importance of using the phrase "going beyond" has become more apparent in the past few years as researchers are finding that STEM alone misses the mark on coverage for process skills and content areas. Increasing the coverage to STEAM or beyond is a move in a positive direction, the arts provide more opportunities for the teacher, and the students to look beyond engineer, math, and science. And using art to gain artistic perspectives and skills to see content in a richer set of dimensions that includes creativity and artistry. What is not included in STEM, STEAM is the learner and how the learner embraces the content and process skills to learn content. This brings in a unique layer-the learner and how to connect the passions of the learner with essential process skills, and then, apply those skills toward specific content areas. The attention at the partnership school is to use a broader focus - to look at "soft skills" as well as hard skills, namely, content knowledge in each of the disciplines. This means that the curriculum supports students' listening to each other, showing respect for each other's ideas, completing a task, and gaining information through reading, writing, listening, and viewing (Oleson, Hora, \& Benbow, 2014).

\section{Purpose of the Paper}

The purpose of this paper is to use a case method design to construct a new model of building a partnership framed on the models of the past and now updated to meet the challenges of 21st century learners through a collective model of shared relationships focused on a common outcome. This paper helps capture the first year of the school-university partnership that emerged from a community-university-school relationship. The voices of the school-university partners are used in this paper to capture shared journeys of the partners to develop a roadmap for a future development of the partnership. Questions that frame this study are: 
1. What were significant initiatives in the past in the school setting that help lay the foundation for the school-university partnership?

2. What are the challenges in today's present time that are being addressed and resolved in building a stronger school-university partnership with the focus on STEM and beyond integration?

3. What are the next steps in studying the relationship building to move systematically into the future built on the STEM to STEAM?

\section{Theoretical Perspective}

Education reform is a complex social problem that no one coalition, government program, organization, or partnership can fix in isolation. Instead of focusing on old methods to produce tired results, "collective impact" offers a new approach. The concept of collective impact is based on the work of Nancy Zimpher (2013) and her involvement with Strive, a subsidiary of Knowledge Works.

Collective impact involves a centralized infrastructure, a dedicated staff, and a structured process that leads to a common agenda, shared measurement, continuous communication, and mutually reinforcing activities among all participants. The shifting from isolated impact to collective impact is not merely a matter of encouraging more collaboration or public-private partnerships. It requires a systemic approach to social impact that focuses on the relationship between organizations and the progress toward shared objectives. (Kania \& Kramer, 2011)

Because collaboration is actually undermined by the near cottage industry of small, boutique partnership activities that may or may not add fundamentally to a more systemic reform agenda (Zimpher \& Howey, 2005), collective impact's overarching strategy is to coordinate improvements at every stage of a young person's life from “cradle” to "grave” (Kania \& Kramer, 2011).

Edmonson and Zimpher (2014) suggested that, “... If major reform or improvements in schools are to occur, they can occur only in conjunction with major reform or improvements in teacher preparation,” and thus, advocated for better K-12 partnerships. They also warned that the complexities of curriculum reform make collaboration between K-12 school personnel and higher education very daunting. Beyond these impediments lie profound differences in culture that limit educational exchanges so necessary school reform. Perhaps even more complicating than these conditions is the notion that most school of education and their respective universities and the schools they serve view themselves already as highly collaborative (Zimpher \& Howey, 2005).

In many cases, partnerships stop or lose their focus without moving to the next step-realignment. Pre-existing partnerships and initiatives will immediately ask, "How do we get started aligning collective impact efforts?" "Who initiates the process?" "Who facilitates it?" "How long does it take?" "Is there a way to anticipate what's needed and have supports ready?” and "How do you manage expectations” (Pittman, 2015)? Those expecting to reap the rewards of a collective impact partnership can expect several identifiable stage - the honeymoon stage, the conflict stage, the confusion-about-democracy stage, the messy stage, the scary stage, and the mature-group stage. One critical component for collective impact initiatives is the creation of a backbone organization. The backbone organization requires a dedicated staff separate from the participating organizations who can plan, manage, and support the initiative through on-going facilitation, technology, communications support, data collection as well as reporting and handling the myriad logistical and administrative details needed for the initiative to function smoothly. The expectation that collaboration can occur without a supporting infrastructure is one of the most frequent reasons why it fails (Kania \& Kramer, 2011). 
Professional development relationships that move into a collective focus have a broader focus that the PDS model that is more commonly understood in today's literature on PDS. The Executive Council and Board of Directors of the National Association for Professional Development Schools (NAPDS) (2008) captured the PDS as a school-university partnership that was structured on nine required essentials. Today, there is a general acceptance that PDS provides a strategy at the national level to prepare effective teachers (NCATE, 2010).

\section{Methodology}

\section{Research Design}

The case study methodology used in this study followed the structure of Yin (2003). Firstly, the case was the most appropriate, as it had an established frame based on past history and a relationship built from the grant that was already in place in the building. Secondly, there was a fixed group at the school site who were familiar with the College of Education faculty. At least $50 \%$ of the staff at the school graduated from the teacher education program in the College of Education. In addition, the principal of the school had used some of the Title 2 funds to support faculty who were willing to support practicum students and interns. Data were collected through notes, interviews, and previous records of initiatives (e.g., science grants and professional development). These data helped frame a holistic analysis of the entire case.

\section{Participants}

There are a set of participants who contributed evidence to this study: the building principal, the cooperating teacher coordinator, the practicum teacher coordinator, the university supervisor linked to pre-service teacher internship, the university field based faculty, the university secondary coordinator, and the university director of teacher education. An important common feature of the participants is that all of them were connected to the initiatives of the middle school as well as the goals for the secondary education program.

\section{Demographics}

District demographics. The study took place at the second largest district in the state of Nevada, a state this is made up of 17 school districts. The district has 104 schools (i.e., 62 elementary schools, 14 middle schools, 15 comprehensive high schools, four alternative schools, nine charter schools, and three integrated pre-schools). The racial breakdown of the district is largely composed of white (45\%) and Hispanic students (40\%).

School district demographics. The middle school in this study has a population that is typical in the district (i.e., 592 students in seven or eight setting). Next year, the school will include 6th grade. Over 81\% of the students qualify for free/reduced lunch, over 27\% of the students are classified as English learners (EL), 17\% are classified as receiving Individualized Educational Program (IEP) service, and over 65\% of the students are from Hispanic families as compared to $21 \%$ white students. The school is classified as a zoom school and qualifies for Title 1 support. Zoom schools have the highest percentage of students who are limited English proficient and provide additional support to their students. The zoom school program began in 2013 and since then, the Nevada Legislature allocated additional funding to provide all middle school zoom schools with free summer school programs that extend the school year by 17 days beyond the state-mandated 180 days of instruction and a zoom school reading skills centers to support early literacy skills

University/College of education demographics. The university with a population of over 20,000 students is a land-grant Tier 1 institution based on the focus on research and funding initiatives. The College of Education has a strong enrollment at both the undergraduate and graduate programs. Over 800 students in K-12 
programs, over $50 \%$ of the students in the teacher preparation program require at least one practicum experience as part of their program, and over $80 \%$ of the teacher educators at the pre-service level are placed in the school district for their internship.

Previous initiatives between school and college of education. The foundation statement captured on the school district website is that the middle school is a beacon for 21st century learning by being one of the first to offer classes in Automation, Robotics, and Aviation Aeronautics. Students focus on complex hands-on activities to explore different design, construction, programming, and commercial applications relating to these fields. The link to the College of Education began with the magnet of STEM. Grants were crafted and funded by both federal and state grants under the leadership of the Raggio STEM center in the College of Education. This led to another grant-funded program-Project Recharge, an innovative technology experiences for students and teachers (ITEST) grant through the national science foundation. This year, Project Recharge was recognized by growing resources for environmental education (GREE) in Nevada as an outstanding educational program. Project Recharge was awarded the Golden Pinecone Award for its success in engaging students, faculty, and staff in local middle schools and high schools to become energy detectives focused on saving their schools thousands of dollars in energy costs. Led by a highly qualified team consisting of the University of Nevada, Reno's Raggio Research center for STEM education and envirolution, a non-profit energy education provider, and the Washoe County School District (WCSD), the students discovered how to build systems and appliances consume energy in their schools. Student groups used tablet computers to interact with real-time data: identifying and tracking major electrical loads in their school buildings. Using this data, student groups submitted proposals with energy conservation opportunities. Students, teachers, envirolution staff, building control services engineers, and school district facility collaborated to implement these recommendations.

\section{Questions That Explored the PDS Case-Year One}

In order to pull together the data at this point in the study, the researchers drafted a set of questions to help gather the awareness of others in the team as well as teachers in the school about the level of understanding of success and challenge to date. The questions were asked of the school key participants (principal, coordinators, practicum teachers, and interns). In addition, practicum students in the 45-hour experience $(N=12)$ and their practicum sponsoring teachers were asked on their rating of the practicum experience during the spring. These ratings were compared to the same questions asked of the practicum students $(N=35)$ in other STEM schools in the same district.

\section{Findings}

\section{Does a School-University Partnership Build a Strong Practicum Experience?}

On a scale of 1 ("Dissatisfied") to 5 (“Outstanding”), practicum students reported that their experience was “Adequate” (33\%), "Very good” (58\%), or “Outstanding” (8\%). There were minimal shifts in classroom practices, such as learning to work in groups, classroom management, correcting student work, pacing, and lesson delivery. Areas that were not as high at the end of the semester included understanding how to ask higher and lower questions and using assessment strategies.

These results were compared to practicum students $(N=35)$ placed in eight other middle schools in the same school district. Three of these schools were STEM focused schools and three of the eight schools were non-Title 1 designated. 
On a scale of 1 ("Dissatisfied”) to 5 (“Outstanding”), practicum students reported that their experience was “Adequate” (17\%), "Very good” (41\%), or "Outstanding” (6\%). The self-ratings of students mirrored the responses of the STEM school focused on in this study. There were minimal shifts in classroom practices, such as learning to work in groups, classroom management, correcting student work, pacing, and lesson delivery. In over $50 \%$ of the responses, students in the non-Title 1 schools rated their experiences as very good or outstanding.

The same sets of questions were used to survey the teachers in the STEM partnership school to the teachers in the non-partnership school. First of all, the teachers in the STEM partnership school had a 75\% response rate as compared to the teachers in the non-partnership school with a low rate of 35\%. Teachers at the partnership school reported that they were more inclusive of the practicum student and encouraged them to take part more in teaching, grading, and providing individual support (e.g., tutoring) for students in their classroom. Teachers in the non-partnership schools were more resistant to allowing the practicum students to teach more than the assigned lesson (one is mandated for the semester). When asked if the teacher was willing to accept a practicum student for the next semester, the teacher in the partnership school was not only willing to accept a practicum student—but even a student teacher.

\section{Challenges Facing School-University Partnerships Today}

The PDS team has meet monthly, invited key change agents, namely, the school staff (building principal, coordinator for practicum students and teachers, and coordinator for cooperating teachers) and College of Education faculty (practicum field-based teacher, secondary coordinator, director of elementary, second and early childhood, and the director the field based/internship experiences). In addition to planning meeting, the team also presented their findings at a school-wide meeting and at two national professional development conferences.

The team recognized that the first year needed to be a time to understand the concept of a PDS with more depth and systematic research on the concepts and challenges of being in a PDS. It became apparent that the team also needed to have more systematic and coordinated research instruments in order to have a pre/post profile of the quality of the practicum experience as well as the internship. The instruments needed to be aligned to the perspectives of the teachers as well as the students in the practicum and internship.

A final objective for Year two is that the teacher education team at the university needs to have more of a presence at the school. It is also important that there is a reciprocal arrangement where the partnership team at the school plays more of a role in shared instruction at teacher preparation class at the university.

\section{What are Next Steps in Studying the Relationship Building to Move Systematically Into the Future?}

The school PDS team - the two coordinators and the building principal attended a PDS conference and presented a paper along with the university PDS faculty. The school team concurred with the university team that the goals of the future need to be aligned with the nine essentials (NAPDS, 2008). The first essential—vision, has served as the starting place to continue this partnership and was well-expressed by the building principal:

A common theme was vision. The building principal explained vision as one that was shared by all and one that supported practicum and intern students in school setting, ensuring a comprehensive experience. What was then concluded is that there is a high-level of collaboration, mutual partnership (expertise and tools shared by both teams), and trust (as evidenced by the support from the building principal). Future vision outcome is that this partnership will help grow solid teachers who can fulfill many of the teaching opportunities in the district. 
The team then used the additional eight essentials to prioritize the goals for the future:

Essential 2: We do have a commitment to this partnership that is public;

Essential 3: We have not fulfilled yet, but beginning due to coming to the site for the staff meeting;

Essential 4: We are committed to reflective practices (through the practicum/intern Guide being a working document, but this is in beginning stages;

Essential 5: Public sharing will be through the community-school-university partnership (CUSP) and the attendance at the two PDS conferences;

Essential 6: We have articulated an agreement delineating roles and responsibilities (This could further develop as the relationship grows);

Essential 7: We have meetings that allow for reflection and collaboration, but have definite room for growth here;

Essential 8: We have begun to have roles across settings, but this is an area of growth;

Essential 9: We have dedicated and shared resources with formal recognition, but as the partnership grows, so will this category.

In conclusion, the main components that we have with this partnership are internship support, practicum support, open communication/reflection of processes and tools, and a strong commitment to do the best thing for students both at the University of Nevada Reno (UNR) and Dilworth Middle School (DMA).

Ultimately, the team concurred that vision and belief were the two elements that helped fuel the start of the UNR partnership. “... Vision and belief that we could do better to support novice teachers, bridging their college work to practical application and experience better." Next steps are to maintain open dialogue, maintaining a set schedule for meetings and that each side of partnership needs to commit resources (human capital and time). On the school site side, having designated people to stand as leads and main points of contact would help set up a better flow of information and more sound scheduling, so that all can be present at PDS meetings. The team also found common meaning by a set of driving questions:

1. What do you anticipate will be future actions in the partnership?

The team agreed that this is the time to use teacher voice and professor voice to increasing more systematic instruments that support interns and practicums. The instruments that are used to provide structure for the pre-service and intern teachers need to align with professional expectation that is in place in the school as well as part of the mission of the university teacher preparation program. It is also an instrument that needs to strengthen practicum and intern practices that have a positive impact in the classroom around instruction, curriculum, assessment, and classroom management.

2. What is your understanding of a partnership? What are components that are present in the school to help construct and implement this relationship?

One observation is that both groups - the teachers at the school and the partnership faculty at the university support STEM education. It is where it all started with science grants and then the project-Project Recharge. Students learned how to collect data and study where data usage could be controlled. It was impressive to work with the community, the school, the funding agency, and the university.

3. What do you believe were attributes that helped this partnership with the College of Education start and continue with high growth?

The most commonly cited attribute was on-going and constant communication between UNR and DMA. One of the coordinators added,

We are in the second semester of the partnership and already, practicum placements have gone much more smoothly due to input between the two groups. We are fortunate to have a building principal is highly supportive of the partnership. All she needed was another partner and we found this in the UNR team. The principal had an enthusiastic openness to 
accept interns and practicum students at the campus and the director of secondary program was able to set up a systematic approach to help the new teachers get the best experiences possible ${ }^{1}$.

4. What do you anticipate will be future initiatives in the partnership?

The response to this question was positive and future anticipation of even more initiatives to come in the future. We anticipate that the partnership will grow, because we have started together at the ground level. We are working with developing and testing daily instruments to glue the partnership together. Another partnership team member added,

As we are more understanding how to better support the lead teaches and the learning teachers at the building, the experience is getting richer for all. We have hit the ground running but are maintaining a systematic approach. In addition, we see that the positions of the support teachers at the school will become formalized job titles and these will be shared district wide. So far, we have observed that practicum students are more prepared to begin student teaching. All teachers involved in the program have helped contribute a sense of welcoming and belonging to the career. I want to think big-it would be great to have classes at the site to have the students have more classroom experiences earlier. Also, we see ourselves as leaders in helping other sites grow their own partnerships use of the information gained from this partnership will be used in future partnerships between the UNR and other WCSD schools.

5. What are instruments (research and pre-service teacher evaluation) that help support the partnership?

We have collaborated on the practicum evaluation based on the district evaluation model (Danielson, 2013) that is administered at the mid-point and at the end of the semester. We also are using a draft model of the practicum handbook that we are encouraging the teachers to provide feedback. We anticipate that it will serve as a template for other schools in the district in the future to help develop more systematic practicum experiences. Continual supervision of practicum students, increased formal observations and input from practicum students and teachers regarding their practicum experience.

\section{Conclusions and Recommendations}

This study is centered in a microcosm-one school within a district that houses over 50 elementary schools. There is a debate that is prevalent in literature at this time: What is a common definition of PDS? (Zenkov, Shiveley, \& Clark, 2016). In this study, the NAPDS (2008) nine essentials were used to set up probes for the team involved in the PDS to date. In addition, the questions that concluded by Zenkov, Shiveley, and Clark, position paper helped frame the success of the first year relationship:

1. What is a PDS? And how do you define PDS in your context?

2. How do you document and evaluate progress in the development of your PDS?

3. How do you assess the impact of your PDS on its various constituents?

4. What criteria do you use to measure the effectiveness, growth, and/or impact of your PDS?

5. What are the highlights and challenges you have encountered in documenting and assessing PDS progress and impact?

It is also in Year two that the team that was involved in Year one continue, but expanded discussion to include in-service and pre-service teachers' voices beyond surveys. Another important set of voices needs to come from university faculty who are involved in the partnership, both in course instruction and in present at the school site. A final commitment from the team at the end of the first year is that teachers, pre-service

\footnotetext{
${ }^{1}$ Fitzpatrick, K. (2017, February 15). Reflection paper on the experience attending a Professional Development School Conference in Myrtle Beach, S.C..
} 
students, as well as university faculty will attend a PDS conference to take part in roundtable discussions and poster presentations. The frame of the nine essentials will continue to serve as the reflection set of points and a comparative analysis on these reflections will compose a scholarly paper at the end of Year two.

\section{References}

Boydell, L., Rugkasa, J., Hoggett, P., \& Cummins, A. (2003). Partnerships: The benefits. Dublin: Institute of Public Health in Ireland.

Buck Institute for Education. (2017). Why project based learning? Retrieved May 5, 2017, from http://www.bie.org/

Corlu, M. A., Capraro, R. H., \& Caprarao, M. M. (2014). Introducing STEM education: Implications for educating our teachers in the age of innovation. Education and Science, 39(71), 74-85.

Danielson, C. (2013). Framework. Retrieved May 6, 2017, from http://www.danielsongroup.org/framework/

Darling-Hammond, L. (1997). The right to learn: A blueprint for developing schools. Canada: Wiley.

Darling-Hammond, L. (2005). Professional development schools: Schools for developing a profession. New York, N.Y.: Teacher College.

Darling-Hammond, L. (2006). Powerful teacher education. San Francisco, C.A.: Jossey-Bass.

Edmondson, J., \& Zimpher, N. L. (2014). Striving together. Albany, N.Y.: SUNY Press.

Fishbough, M. (2007). Models of collaboration. Boston: Allyn Bacon.

Garrison, C., \& Chandler, D. (2009). Effective classroom assessment: Linking assessment with instruction. Westerville, Ohio: National Middle School Association and Measured Progress.

Holmes Group (1990). Tomorrow's schools: A report of the Holmes group. Retrieved May 5, 2017, from https://eric.ed.gov /?id=ED399220

Kania, J., \& Kramer, M. (2011, winter). Collective impact. Retrieved June 30, 2015, from http://www.ssireview.org/articles/entry /collective_impact

Kasza, P., \& Slater, T. F. (2017). A survey of best practices and key learning objectives for successful secondary school STEM academy settings. Contemporary Issues in Education Research, 10(1), 53-66.

Mohr, N., \& Dichter, A. (2003). Stages of team development: Lessons from the struggles of site-based management. In Writing within school reform. Providence, R.I.: Annenberg Institute for School Reform at Brown University.

Morrison, J., Roth M. A., \& French, B. (2015). Identifying key components of teaching and learning in a STEM school. School Science and Mathematics, 115(5), 244-255. Retrieved May 6, 2017, from http://doi.org/10.1111/ssm.12126

Murrell, P. C. (1998). Like stone soup: The role of the professional development school in the renewal of urban schools. USA: Washington, D.C.: American Association of Colleges for Teacher Education (AACTE). ISBN-0-89333-167-8

National Association for Professional Development Schools (NAPDS). (2008). What it means to be a professional development school. Retrieved May 5, 2017, from http://wwww.napds.org/nine_essen_html

National Council for the Accreditation of Teacher Education (NCATE). (2010). Transforming teacher education though clinical practice: A national strategy to prepare effective teachers. In A Report of the Blue Ribbon Panel on Clinical Preparation and Partnership for Improved Student Learning. Washington, D.C..

National Council for Restructuring Education, Schools, and Teaching (NCREST). (2017). Welcome to NCREST. New York, N.Y.: Columbia University. Retrieved May 15, 2017, from http://www.tc.columbia.edu/ncrest/index.html

National Governors Association (NGA). (2007). Innovation America: Building a science, technology, engineering, and math (STEM) agenda. Retrieved April 11, 2017, from http://www.nga.org/files/live/sites/NGA/files/pdf/0702INNOVATIONSTE M.PDF

Nevada Department of Education (2017). Nevada's read by Grade 3 program. Retrieved April 12, 2017, from http://www.doe.nv.gov/RB G3/Home/

Oleson, A. K., Hora, M. T., \& Benbow, R. J. (2014). STEM: How a poorly defined acronym is shaping education and workforce development policy in the United States. Wisconsin Center for Education Research (WCER) Working Paper (No. 2014-2). Retrieved April 11, 2017, from http://eric.ed.gov/?id=ED556481

Pittman, K. (2015, February). How to partner for impact: The nuts and bolts of aligning collective impact efforts. Retrieved April 11, 2017, from http://www.collectiveimpactforum.org/blogs/1616/how-partner-impact-nuts-and-bolts-aligning-collective-im pact-efforts

Yin, R. K. (2003). Case study research: Design and method (3rd ed.). Thousand Oaks, C.A.: Sage. 
Zenkov, K., Shiveley, J., \& Clark, E. (2016). Why we must answer the question "What is a professional development school?” School-University Partnership, 9(3), 1-10.

Zimpher, N. L., \& Howey, K. R. (2005). The politics of partnerships for teacher education redesign and school renewal. Journal of Teacher Education, 56(3), 266-271. doi:10.1177/0022487105275922

Zimpher, N. L. (2013). Nancy Zimpher highlights excellent in teacher preparation. Retrieved April 3, 2017, from https://www.suny.edu/suny-news/press-releases/june-2013/6-17-13-nz-highlights-excellence-in-teacher-prep/6-17-13-chance llor-zimpher-highlights-excellence-in-teacher-preparation-programs-.html

\section{Appendix}

\section{Practicum Student Survey—Pre and Post}

Practicum Teacher Evaluation

Practicum teacher:

School name:

Practicum student name:

Date of evaluation:

Practicum teacher: Your practicum student is expected to teach at least one complete lesson (one hour in your classroom during the semester. Please rate your practicum student in the following four domains of professional competence. Each domain has a few questions or prompts that need to be answered with a rating. Additionally, any comments or suggestions for improvements for the remainder of the student's time in the program or out in the field would be very helpful. Please complete the evaluation two times - at the midpoint of the experience and at the end of the experience. Know that the PDS team can meet with you at each of these checkpoints to discuss the progress and future goals for your practicum student.

Thank you again for your time.

\begin{tabular}{|l|l|l|l|l|}
\hline 1 Inadequate & $2=$ Below average & 3 = Average & $4=$ Above average & $5=$ Outstanding \\
\hline
\end{tabular}

Domain 1: Planning and Preparation

\begin{tabular}{|c|c|c|c|c|}
\hline How adequate was the practicum student's knowledge of the content area? & & 2 & 3 & 4 \\
\hline $\begin{array}{l}\text { How well did the practicum student use curriculum goals and standards to develop meaningful lessons that could } \\
\text { connect to his/her students? }\end{array}$ & & 2 & 3 & 4 \\
\hline How well did the practicum student make an attempt to get to know the students whom they were teaching? & 1 & 2 & 3 & 4 \\
\hline $\begin{array}{l}\text { How well did the practicum student recognize that the classroom was a community of learners who experience } \\
\text { learning in various ways? }\end{array}$ & 1 & 2 & 3 & 4 \\
\hline
\end{tabular}

Domain 2: The Classroom Environment

\begin{tabular}{|l|l|}
\hline $\begin{array}{l}\text { How well did the practicum student encourage the learning processes and try to assist, prompt, or monitor students } \\
\text { whenever possible? }\end{array}$ & 12345 \\
\hline Did the practicum student exhibit a positive attitude toward schools, teaching, students, and parents? & 12345 \\
\hline $\begin{array}{l}\text { How well did the practicum student demonstrate an ability to manage the students? Effective classroom } \\
\text { management? }\end{array}$ & 12345 \\
\hline $\begin{array}{l}\text { How well did the practicum student respect all students and require respect when students interacted with each } \\
\text { other? }\end{array}$ & 12345 \\
\hline Explanations (if needed): & \\
\hline
\end{tabular}


Domain 3: Instruction

\begin{tabular}{|l|l|}
\hline How well did the practicum student give clear and direct instructions regarding expectations of lesson? & 12345 \\
\hline How well did the practicum student pace the lesson and plan for effective transitions? & 12345 \\
\hline $\begin{array}{l}\text { How well did the practicum student understand different types of assessment and demonstrate the ability to use } \\
\text { these to plan, evaluate, and strengthen instruction? }\end{array}$ & 12345 \\
\hline $\begin{array}{l}\text { How well did the practicum student demonstrate awareness of how and when to give feedback to a student, either } \\
\text { when teaching, monitoring, or assisting with the class? }\end{array}$ & 12345 \\
\hline $\begin{array}{l}\text { How well did the practicum student use a variety of instructional materials and approaches to deliver instruction } \\
\text { clearly and effectively? }\end{array}$ & 12345 \\
\hline Was the practicum student flexible and able to make adjustments to changing student needs and circumstances? & 12345 \\
\hline Explanations (if needed): & \\
\hline
\end{tabular}

Domain 4: Professional Responsibilities

Did the practicum student dress appropriately for the situation and wear appropriate attire for teachers in the school?

Was the practicum student receptive and responsive to professional feedback incorporating suggestions into practice?

Did the practicum student reflect on and evaluate his or her own behavior and work? Was he or she willing to consider multiple perspectives of his or her own performance?

12345

Did the practicum student voluntarily participate in a variety of classroom and school duties that are necessary for

the classroom teacher such as hall duty, gathering and setting up materials for activities, grading student work or 12345 tutoring small groups?

Was the practicum student willing and able to recognize his/her own difficulties or deficiencies within his/her content or pedagogical knowledge and begin to develop potential solutions?

Did the practicum student demonstrate a positive attitude when working with both the lead teacher and other school staff members?

Explanations (if needed):

Comments, concerns, and recommendations:

\section{Practicum Student Self-Evaluation Midterm and Final}

Practicum teacher:

School name:

Practicum student name:

Practicum student: Please rate yourself in the following four domains of professional competence. Each domain has a few questions or prompts that need to be answered with a rating. Additionally, any comments or suggestions for improvements for the remainder of your time in the practicum, or out in the field, would be very helpful.

Thank you again for your time, and let me know if you have any questions. We will discuss this self-evaluation during the class time or through an individual scheduled conference.

\begin{tabular}{|l|l|l|l|l|}
\hline 1 = Inadequate & $2=$ Below average & 3 = Average & $4=$ Above average & $5=$ Outstanding \\
\hline
\end{tabular}

Domain 1: Planning and Preparation

How adequate would you rate your knowledge of the content area?

How well would you rate your use of curriculum goals and standards to develop meaningful lessons that could connect to the students?

How well would you rate your efforts to get to know the students to whom you are teaching?

12345

How well would you rate you understanding that the classroom is a community of learners who experience learning in various ways?

12345

Explanations (if needed):

12345

12345 
Domain 2: The Classroom Environment

\begin{tabular}{|l|l|}
\hline $\begin{array}{l}\text { How well would you rate and how well you encouraged the learning processes and try to assist, prompt, or monitor } \\
\text { students whenever possible? }\end{array}$ & 12345 \\
\hline How well would you rate your efforts to set up a positive attitude toward schools, teaching, students, and parents? & 12345 \\
\hline How well would you rate your ability to manage the students? Effective classroom management? & 12345 \\
\hline $\begin{array}{l}\text { How well would you rate and how well you showed respect all students and required respect when students } \\
\text { interacted with each other? }\end{array}$ & 12345 \\
\hline Explanations (if needed): & \\
\hline
\end{tabular}

Domain 3: Instruction

How well would you rate and how well you give clear and direct instructions regarding expectations of lesson? How well would you rate your pace in the lesson and plan for effective transitions?

12345

How well would you rate your understanding of different types of assessment and demonstrate the ability to use these to plan, evaluate, and strengthen instruction?

How well would you rate your ability to demonstrate awareness of how and when to give feedback to a student, either when teaching, monitoring, or assisting with the class?

How well would you rate your use a variety of instructional materials and approaches to deliver instruction clearly and effectively?

How well would you rate your flexibility and able to make adjustments to changing student needs and circumstances?

Explanations (if needed):

Domain 4: Professional Responsibilities

How well would you rate your dress as appropriate for the situation and wear appropriate attire for teachers in the school?

\begin{tabular}{|l|l|l}
\hline How well would you rate your responsiveness to professional feedback incorporating suggestions into practice? & 12345 \\
\hline
\end{tabular}

How well would you rate your reflection on and evaluation on your own behavior and work? Were you willing to consider multiple perspectives of your performance?

How well would you rate the degree to which you voluntarily participated in a variety of classroom and school duties that are necessary for the classroom teacher such as hall duty, gathering, and setting up materials for activities, grading student work or tutoring small groups?

How well would you rate your willing and able to recognize your own difficulties or deficiencies within your content or pedagogical knowledge and begin to develop potential solutions?

How well would you rate your demonstration of a positive attitude when working with both the lead teacher and other school staff members?

Explanations (if needed):

Comments, concerns, and recommendations: 